\title{
Current Status for Oral Platinum (IV) Anticancer Drug Development
}

\author{
Qian Mi*, Shunshun Shu*, Caixia Yang, Chuan Gao, Xian Zhang, Xiao Luo, Chonghuan Bao, \\ Xia Zhang, Jun Niü
}

Quality Inspection and Control Center, C.P. Food ( Xiangyang) Co., Ltd., Xiangzhou District, Xiangyang, China

Email: 1013360845@qq.com

How to cite this paper: Mi, Q., Shu, S.S., Yang, C.X., Gao, C., Zhang, X., Luo, X., Bao, C.H., Zhang, X. and Niu, J. (2018) Current Status for Oral Platinum (IV) Anticancer Drug Development. International Journal of Medical Physics, Clinical Engineering and Radiation Oncology, 7, 231-247.

https://doi.org/10.4236/ijmpcero.2018.72020

Received: April 8, 2018

Accepted: May 27, 2018

Published: May 30, 2018

Copyright $\odot 2018$ by authors and Scientific Research Publishing Inc. This work is licensed under the Creative Commons Attribution International License (CC BY 4.0).

http://creativecommons.org/licenses/by/4.0/ (c) (i) Open Access

\begin{abstract}
Platinum-based chemotherapeutic drugs such as cisplatin, carboplatin and oxaliplatin are widely applied for the treatment of various types of tumors. However, poor solubility, serious side effects, and more importantly, the intrinsic and acquired resistance limit their clinical applications. These factors motivate scientists to design and synthesize novel and more potent analogues lacking disadvantages of clinical platinum drugs. Platinum (IV) complexes are one of representatives. In this review, we summarized the investigations undertaken into Platinum (IV) antitumor compounds since Rosenberg first noted their antitumor activity. The synthesis method and mechanism of action of Platinum (IV) complexes are outlined, as well as their chemical and pharmacological properties. Recent advances in Platinum (IV) anticancer agents that have been in clinical trials and photoactivatable Platinum (IV) complexes are also summarized, and the purpose here is to provide insight into the requirements for the antitumor activity of Platinum (IV) complexes and a basis for progressing in a new platinum compound.
\end{abstract}

\section{Keywords}

Platinum (IV) Complexes, Properties, Mechanism, Antitumor Activity, Cancer Therapy, Photoactivatable

\section{Introduction}

Cancer, as the leading cause of death in developed countries and the second cause of death in developing countries [1], seriously threatens human's health and life. At present, surgery (removal of solid tumor when localised in a specific tissue), radiotherapy (radiation with X-ray beam) and chemotherapy (use of anti-proliferative

${ }^{\star}$ First Author

\#Corresponding Author 
drugs) are three main strategies for the treatment of cancer. In the last category, platinum drugs are used to treat over $40 \%$ of all cancer patients [2]. For this reason, platinum-based drugs are one of the most important classes of chemotherapeutic agents for cancer chemotherapy.

Platinum complexes have become a new type of inorganic anticancer agents since the discovery of the antitumor properties of cisplatin(cis- $\left.\left[\mathrm{PtCl}_{2}\left(\mathrm{NH}_{3}\right)_{2}\right]\right)$ (Figure 1) by Rosenberg and his colleagues [3]. Together with carboplatin and oxaliplatin (Figure 1), they represent all of the available platinum-based therapeutic drugs approved by FDA in clinical use for various cancers [4] [5], where it is most commonly used in combination with other drugs [6]. However, the clinical utility of them is restricted by various side effects such as nephrotoxicity, inherent and acquired resistance, which significantly degrade life quality of cancer patient, leading to a dismal prognosis [7] [8]. In addition to above substantial limitations, all these three drugs are administered by intravenous infusion in clinical practice. Oral drugs are simpler to use and less expensive than those requiring intravenous administration. However, their oral administration is hampered by poor bioavailability, acute emesis and toxicity to the intestinal mucosa [9]. For these reasons, vast efforts are committed to developing novel platinum-based complexes. Platinum (IV) complexes are one example of this class of antitumor agents.

In recent years, $\mathrm{Pt}$ (IV) complexes act as a potential alternative suitable for oral administration to the traditional Pt (II) drugs [10] because these complexes are toxic to tumors which are resistant to cisplatin. A wide range of Pt (IV) complexes' anticancer activity depends on their axial and equatorial ligands. The two additional ligands in axial position could be used to tune the lipophilicity, the rate of reduction and then the overall pharmacokinetic profile [11]. The advantages and disadvantages of certain platinum (II) and Platinum (IV) complexes are shown in the Table 1.

Knowledge of the kinetics and property of Pt (IV) compounds has promoted the development of potent platinum-based antitumor drugs with suitable properties for oral administration and antitumor activity in cisplatin-resistant human cancer cells. In this mini review, we mainly focus on the current progress of Platinum (IV) complexes by summarizing the investigations undertaken into Platinum (IV) antitumor compounds since Rosenberg first noted the activity of tetraplatin.

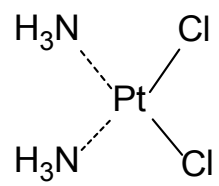

Cisplatin 1 (world-wide approved in 1978)

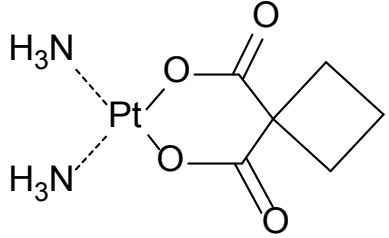

Carboplatin 2 (world-wide approved in 1993)<smiles>O=C1O[PH]2(N[C@H]3CCCC[C@H]3N2)OC1=O</smiles>

Oxaliplatin 3 (world-wide approved in 2002)

Figure 1. Structures of classical and current world-wide antitumor platinum drugs. 
Table 1. The advantages and disadvantages of certain Platinum (II) and Platinum (IV) complexes.

\begin{tabular}{|c|c|c|c|}
\hline Classification & Names & Advantages & Disadvantages \\
\hline \multirow[t]{3}{*}{$\begin{array}{l}\text { Pt (II) } \\
\text { complexes }\end{array}$} & Cisplatin & $\begin{array}{l}\text { broad antibacterial } \\
\text { spectrum, high } \\
\text { antitumor activity }\end{array}$ & $\begin{array}{l}\text { poor water solubility, nephrotoxicity, } \\
\text { acute emesis, cough, drug resistance, } \\
\text { intravenous administration etc. }\end{array}$ \\
\hline & Carboplatin & $\begin{array}{l}\text { good antitumor activity, } \\
\text { no obvious } \\
\text { nephrotoxicity }\end{array}$ & $\begin{array}{l}\text { Myelosuppression, platelet disorders, drug } \\
\text { resistance, intravenous administration, } \\
\text { peripheral neurotoxicity, etc. }\end{array}$ \\
\hline & Oxaliplatin & $\begin{array}{l}\text { no drug resistance, good } \\
\text { activity, low side effect }\end{array}$ & $\begin{array}{l}\text { neurotoxicity, alimentary canal toxicity, } \\
\text { intravenous administration, etc. }\end{array}$ \\
\hline \multirow[t]{3}{*}{$\begin{array}{l}\text { Pt (IV) } \\
\text { complexes }\end{array}$} & Satraplatin & $\begin{array}{l}\text { better effect, oral } \\
\text { administration, no } \\
\text { resistance, low side } \\
\text { effect }\end{array}$ & $\begin{array}{l}\text { dose-limiting myelosuppression and } \\
\text { emesis }\end{array}$ \\
\hline & Ormaplatin & $\begin{array}{l}\text { no neurotoxicity and } \\
\text { nephrotoxicity, better } \\
\text { effect, oral } \\
\text { administration, no drug } \\
\text { resistanc }\end{array}$ & Unpredictable peripheral neurotoxicity \\
\hline & Iprolatin & $\begin{array}{l}\text { high water solubility, no } \\
\text { drug resistance, oral } \\
\text { administration }\end{array}$ & less effect \\
\hline
\end{tabular}

\section{The Structure and Synthesis of Pt (IV) Complexes}

As a prodrug, the general structure formula of $\mathrm{Pt}$ (IV) is cis, cis, trans- $\left[\mathrm{Pt}(\mathrm{Am})_{2} \mathrm{X}_{2} \mathrm{Y}_{2}\right]$. Wherein " $\mathrm{X}$ " is a leaving group and "Am" contains amino ligands, while "Y" is axial ligand. These ligands of Pt (IV) complexes have adopted the six-coordinated, forming octahedral geometry. Such configuration has replaced the kinetic inertness and decreased the reaction activity.

At present, the first step to synthesize Pt (IV) complex is to construct the corresponding Pt (II) complexes, which can be transformed into Pt (IV) complexes via ligand substitution or oxidation reaction with chlorine or hydrogen peroxide. Axial dihydroxo Pt (IV) complexes resulting from an oxidation of predesigned $\mathrm{Pt}$ (II) are further concerted into carboxylato complexes by carboxylation [12].

\section{Mechanism of Action of Platinum (IV) Complexes}

Platinum (IV) complexes, as one class of prodrugs, are accepted by the majority of scholars. Since Pt (IV) complexes are considerably more inert kinetically than their Pt (II) analogues [13], a central question is how they may be activated to produce their antitumor effects in vivo. It is widely believed that Platinum (IV) complexes to exert their anticancer activity are reduced to platinum (II) by potential bio-reductants [14]. The resulting more reactive Pt (II) analogs were ac- 
tivated to the usual diaqua-Pt (II) species by the normal hydrolysis reaction. Then the diaqua-Pt (II) species form adducts with DNA (inter and intrastrand DNA cross-links), leading to conformational changes of DNA and destructing the biological function of DNA (Figure 2), thereby affecting large number of transduction pathways and triggering apoptosis or necrosis [15] [16] [17].

Tobe [18] and later Cleare et al. [19] suggested the reduction hypothesis, which was reinforced when it was observed that patients receiving iproplatin, cis, trans, cis- $\left[\mathrm{PtCl}_{2}(\mathrm{OH})_{2}\left(\left(\mathrm{CH}_{3}\right)_{2} \mathrm{CHNH}_{2}\right)_{2}\right]$, in clinical trials had cis- $\left[\mathrm{PtCl}_{2}\left(\left(\mathrm{CH}_{3}\right)_{2} \mathrm{CHNH}_{2}\right)_{2}\right]$ in their plasma and urine indicating that iproplatin was reduced to a Pt (II) complexin the body. Studies on iproplatin and oxoplatin by Blatter et al. showed that neither forms adducts with DNA unless a reducing agent (Fe(II) or ascorbic acid) was added [20] [21], leading to the conclusion that reduction is required for their activity.

However, Platinum (IV) complexes binding directly to DNA was reported by some scholars [22] [23]. DNA binding by iproplatin and oxoplatin invitro was observed by Brabec and co-workers, and they concluded that Platinum (IV) complexes were coordinating monofunctionally without reduction [24]. The reaction of DNA with the tetraplatin which indicates direct DNA binding, followed by cleavage of the DNA on reduction was investigated by Choi and co-workers [25].

So Pt (IV) complexes can overcome the problem of traditional Pt (II) anticancer drug, such as side effects and drug resistance. Besides, they can be administered orally, which overcome the intravenous administration of traditional Pt (II) drug.

\section{Structure-Activity Relationship on Platinum (IV) Complexes}

Pt (IV) complexes are generally considered as prodrugs, which undergo reduction in the intracellular milieu. During this process, the axial ligands are released and
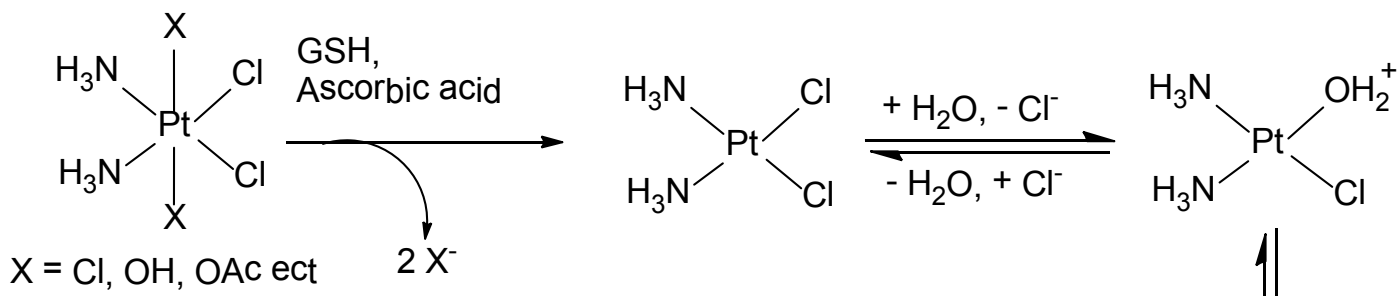<smiles></smiles>

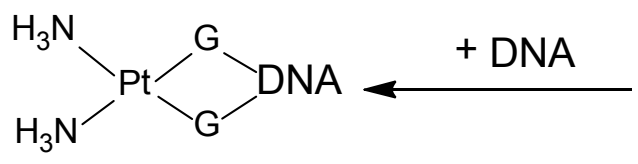<smiles>N[PH3+](N)O</smiles>

Intras trand GG-Crosslinks

Figure 2. Mechanism of activation of classical antitumor active Pt (II) and Pt (IV) Diam(m)ines. 
the corresponding anticancer active Pt (II) analogs are formed. Therefore, the activity of Pt (IV) anticancer drugs is strongly influenced by their reduction potential [26] [27]. Several studies show that the reduction potentials of diam(m)ine Platinum (IV) complexes are susceptible to the nature of the axial and equatorial ligands, but the axial ligands generally exert the stronger influence [28]. For Pt (IV) complexes, reduction most easily occurs when chlorido ligands are in the axial position; Carboxylato ligands lead to an intermediate reduction potential, whereas hydroxido ligands possess strong electron donating properties resulting in low reduction potentials [28] [29] [30]. Many studies on the mechanism of reduction of $\mathrm{Pt}$ (IV) complexes are reported, but it seems clear that it is difficult to establish the correlation between potential and rate of reduction. Choi et al. suggested that the reduction rates depend not only on the electron-withdrawing power of the axial ligands but also on the bulkiness of these ligands [31]. The complex with a bulkier and more electron withdrawing ligand shows a higher reduction rate and reduction potential. The reduction rate of Platinum (IV) complexes was dependent on both $\sigma$-donor ability and steric hindrance of $\mathrm{R}$ in equatorial amine ligands. JM216 and iproplatin are reduced more rapidly than cis, trans- $\left[\mathrm{PtCl}_{2}(\mathrm{en})\left(\mathrm{OCOCH}_{3}\right)_{2}\right]$, which was ascribed to the steric bulk of the amine ligands onJM216 and iproplatin relativeto the ethane-1,2-diamine ligand complex. Oxidation of these compounds to produce Pt (IV) dihydroxy compounds followed by being further functionalized to form carboxylates, carbonates and carbamates [32] that would influence pharmacokinetics but would be lost prior to forming the active DNA lesion.

In a homologous series of Platinum (IV) complexes, the increase of ligand hydrophobicity is positively correlated with the increase of the cytotoxic effect [33]. The effectiveness of the Pt (IV) dicarboxylate compounds in cisplatin-resistant cells may be a result of their lipophilic facilitating transport into the cell [34]. The higher hydrophobicity of the platinum complexes enhanced their penetration through the cell membrane and increased their accumulation inside the cancer cells. The authors demonstrated that when the leaving groups are unchanged, the hydrophobicity of aplatinum complex is linearly related to that of theam(m)ine. The increasing cytotoxicity trend in the series of Pt (IV) carboxylates, is related to increased transportinto cells as the lipophilicity of the complexes increase [35]. The antiproliferative activity of a series of cisplatin-based Pt (IV) prodrug candidates having a large interval of lipophilicity, namely trans, cis, cis- $\left[\mathrm{Pt}(\text { carboxylato })_{2} \mathrm{Cl}_{2}\left(\mathrm{NH}_{3}\right)_{2}\right]$ (Figure 3), where carboxylato $=\mathrm{CH}_{3}\left(\mathrm{CH}_{2}\right)_{\mathrm{n}} \mathrm{COO}^{-}$ [(1), $n=0 ;(2), n=2 ;(3), n=4 ;(4), n=6]$ were studied on a large panel human cancer cell lines by Zanellato et al. [36]. As expected, the potency increases with the chain length 3 and 4 resulted by far more active than cisplatin on all cell lines. Both complexes retained their antiproliferative activity also against cisplatin-resistant cell lines, and exhibited the high selectivity compared with non-tumor cells.

Although increasing lipophilicity makes the compound more vulnerable to 


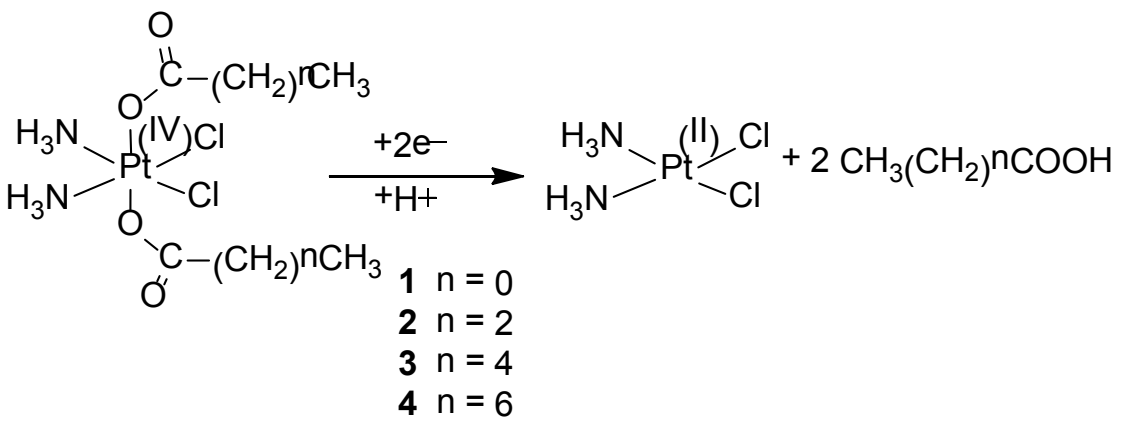

Figure 3. Chemical Structures of Pt (IV) Complexes 1-4 and Proposed Activation Pathway. The studies showed that potency increases with the chain length $\mathbf{3}$ and $\mathbf{4}$ resulted by far more active than cisplatin on all cell lines.

hepatic metabolism, it usually enhances oral absorption and biodistribution. An excessive increase of lipophilicity strongly decreases the water solubility of the compound and its hydrogen bonding ability, thus limiting bioavailability.

The above-mentioned effects should be taken into account when developing new strategies targeting Platinum (IV) drugs. Thus, an oral candidate drug must be of an appropriate size, lipophilicity and hydrogen bonding characteristics to facilitate oral absorption and enhance bioavailability, which provide a basis for rational design of new Platinum (IV) drugs with suitable pharmacokinetic and pharmacodynamics properties.

\section{Novel Platinum (IV) Complexes and Their Biological Effects}

In the recent years, researchers developed several Platinum (IV) analogs, for example ormaplatin, lobaplatin, nedaplatin, iproplatin as well as photoactivable complexes, respectively [37] [38] [39] [40] [41]. Compared with platinum (II) drugs, these complexes have lower reactivity that would diminish loss of active drug, prolong stability of the drug in the bloodstream and lower the incidence of unwanted side reactions [12]. Moreover, introduce of two extra axial ligands can be changed to modify their pharmacokinetic parameters such as their rate of reduction and lipophilicity. The modulation of these parameters might increase the activity of the complexes and efficacy in cisplatin-resistant tumor cell lines or confer additional cytotoxicity [42] [43].

These suitable properties of Pt (IV) complexes make them possible to be promising and usable anticancer candidates, so researchers have made vast efforts to develop orally active Pt (IV) antitumor compounds. Christen et al. synthesized a series of Pt (IV) compounds that exhibit excellent antitumor activity. One of them, JM-216, as the first oral Platinum (IV) complex that has entered clinical trial, showed promise in patients with hormone-refractory prostate cancer. In preclinical study, it has shown antitumor activity far superior to that boseved for cisplatin, carboplatin against a panel of human cancer cell lines consisting of Pt-sensitive and -resistant cell lines with either acquired or intrinsic resistance to cisplatin. Furthermore, it has been shown to have less-toxic side effects (nephrotoxicity, neurotoxicity, myelosuppression etc.) than cisplatin in 
clinical trials [44]. Due to the importance and outstanding features of these derivatives as antitumor agents, many novel Platinum (IV) complexes with high activity in vitro have been synthesized in recent years. For example, Moghaddas et al. had designed and systhesized a class of Platinum (IV) pyrophosphato-complexes (Figure 4) and these complexes showed impressive in vitro toxicity, especially in cisplatin- and carboplatin-resistant human ovarian cancer cells [45]. They made a conclusion that phosphaplatins exhibited superior efficacy and reduced toxicity compared to several platinum therapies for current ovarian cancers treatment.

Recently, Keppler's group has reported cis-Diam(m)inebis(carboxylato) dichloride Platinum (IV) and cis-diam(m)inetetrakis(carboxylato) Platinum (IV) complexes (Figure 5) with cytotoxicity ranging from low nanomolar to high micromolar $\mathrm{IC}_{50}$ values [46] [47] [48] [49] [50], and demonstrated theoretical and QSAR investigations on these novel Platinum (IV) complexes. All these above respects reflect the major trends in this field, which provide some valuable information for researchers pursuing new Platinum (IV) anticancer agents.

\section{Current Status of Orally Active Platinum (IV) Complexes That Have Entered Clinical Trials}

The development of Pt (IV) complexes provides a new opportunity for emergence of the novel platinum drugs that could potentially decrease the side effects shown by the conventional Pt (II) drugs. So far, five Pt (IV) drug candidates have entered clinical trials or have been used clinically (Figure 6): Iproplatin, Ormaplatin, oxoplatin, LA12 and JM216 (satraplatin). The first two have experienced a large number of animal experiments and clinical trials. Ormaplatin showed great promise in preclinical studies and had entered in phase I trials for the treatment of breast cancer, ovarian cancer and myeloma cancer. However, in the testing process, severe neurotoxicity appeared, resulting in no further phase II and phase III clinical trials. Iproplatin was selected from a range of Platinum (IV) complexes for its high solubility [51] and entered phase III clinical trials for treatment of ovarian cancer, exhibiting improved antitumor activities with reduced toxicity. But it was ultimately found to be less active than cisplatin and carboplatin, so has not entered widespread clinical use [27] [40].

Oxoplatin, an orally applicable Pt (IV) drug, has been used clinically [40]. Presnov et al. found that oxoplatin displayed a prolonged effect, antimetastatic activity, and similar or even higher tumor growth inhibition. It is believed to be<smiles>N[C@H]1CCCC[C@H]1N[P]1(O)OP(=O)(O)OP(=O)(O)O1</smiles><smiles>N[C@H]1CCCC[C@H]1N[P]1(O)OP(=O)(O)OP(=O)(O)O1</smiles><smiles>O=P1(O)OP(=O)(O)O[P+](O)(N[C@@H]2CCCC[C@@H]2N[C@@H]2CCCC[C@@H]2O)O1</smiles>

Figure 4. Structural formulas of various isomers of Platinum (IV)-pyrophosphato complexes containing 1,2-cyclohexanediamine Ligand. 
<smiles>[X]CC(=O)C[PH](CC([R])=O)(CC([Y])=O)(N[R])N[R]</smiles><smiles>[R]C(=O)CCC(=O)C[PH](N)(N)CC(=O)CCC([R])=O</smiles>

$\left.\mathrm{R}=\mathrm{OH}, \mathrm{OCH}_{2} \mathrm{CH}_{3}, \mathrm{NH}_{(} \mathrm{CH}_{2}\right)_{2} \mathrm{OH}$, $\mathrm{NH}\left(\mathrm{CH}_{2}\right)_{2} \mathrm{CH}_{3}, \mathrm{NH}-\mathrm{Cp}$<smiles>[R]C(=O)CCC(=O)CP(N)(N)(CC(=O)CCC([R])=O)OC(=O)CO</smiles>

$\mathrm{R}=\mathrm{OH}, \mathrm{O}\left(\mathrm{CH}_{2}\right)_{2} \mathrm{CH}_{3}, \mathrm{NH}-\mathrm{Cp}$<smiles>[X]CC(=O)C[P+](N)(N)OC(=O)CC([R])=O</smiles>

1. $X=\mathrm{CH}_{2}, \mathrm{R}=\mathrm{OH}, \mathrm{OCH}_{3}, \mathrm{O}\left(\mathrm{CH}_{2}\right)_{2} \mathrm{CH}_{3}, \mathrm{O}\left(\mathrm{CH}_{2}\right)_{3} \mathrm{CH}_{3}$, $\mathrm{OCH}_{2} \mathrm{CH}_{3}, \mathrm{OCH}\left(\mathrm{CH}_{3}\right) \mathrm{CH}_{3}, \mathrm{NH}-\mathrm{bz}, \mathrm{NH}-\mathrm{Cp}$, $\mathrm{NH}-\mathrm{Ch}, \mathrm{NH}\left(\mathrm{CH}_{2}\right)_{2} \mathrm{OCH}_{3}, \mathrm{NH}\left(\mathrm{CH}_{2}\right)_{2} \mathrm{CH}_{3}$

2. $\left.X=\left(\mathrm{CH}_{2}\right)_{2}, \mathrm{R}=\mathrm{OH}, \mathrm{OCH}_{3}, \mathrm{OCH}_{2} \mathrm{CH}_{3}, \mathrm{NH}_{(} \mathrm{CH}_{2}\right)_{2} \mathrm{CH}_{3}$

3. $\mathrm{X}=\mathrm{CH}\left(\mathrm{CH}_{3}\right) \mathrm{CH}_{2}, \mathrm{R}=\mathrm{OH}, \mathrm{OCH}_{3}, \mathrm{NH}\left(\mathrm{CH}_{2}\right)_{2} \mathrm{CH}_{3}$

4. $\mathrm{X}=\mathrm{C}\left(\mathrm{CH}_{3}\right)_{2} \mathrm{CH}_{2}, \mathrm{R}=\mathrm{OH}, \mathrm{OCH}_{3}, \mathrm{NH}\left(\mathrm{CH}_{2}\right)_{2} \mathrm{CH}_{3}$<smiles>[R]C(=O)CCC(=O)CP(Cl)(CC(=O)CCC([R])=O)(NCC)NCC</smiles>

$\mathrm{R}=\mathrm{OH}, \mathrm{OCH}_{3}, \mathrm{OCH}_{2} \mathrm{CH}_{3}, \mathrm{NH}-\mathrm{Cp}$

$\left.\mathrm{O}\left(\mathrm{CH}_{2}\right)_{2} \mathrm{CH}_{3}, \mathrm{OCH}_{(} \mathrm{CH}_{3}\right) \mathrm{CH}_{3}$<smiles>[R]C(=O)CCC(=O)C[P+](CC(=O)CCC([R])=O)(CC(=O)CCC([R])=O)NC1CCCC[C@@H]1N</smiles>

$\mathrm{R}=\mathrm{OH}, \mathrm{OCH}_{2} \mathrm{CH}_{3}$, or $\left.\mathrm{NH}_{(} \mathrm{CH}_{2}\right)_{2} \mathrm{CH}_{3}$<smiles>[X]CC(=O)C[P+](Cl)(NCCC([R])=O)NCC([R])=O</smiles>

1. $\mathrm{X}=\mathrm{CH}_{2}, \mathrm{R}=\mathrm{OH}, \mathrm{OCH}_{3}, \mathrm{OCH}_{2} \mathrm{CH}_{3}$ $\mathrm{O}\left(\mathrm{CH}_{2}\right)_{2} \mathrm{CH}_{3}, \mathrm{NH}-\mathrm{Cp}, \mathrm{O}\left(\mathrm{CH}_{2}\right)_{3} \mathrm{CH}_{3}$, $\left.\mathrm{NH}\left(\mathrm{CH}_{2}\right)_{2} \mathrm{OH}, \mathrm{NH}_{(} \mathrm{CH}_{2}\right)_{2} \mathrm{CH}_{3}$

2. $\mathrm{X}=\left(\mathrm{CH}_{2}\right)_{2}, \mathrm{R}=\mathrm{OH}, \mathrm{OCH}_{2} \mathrm{CH}_{3}, \mathrm{NH}-\mathrm{Cp}$, $\left.\mathrm{NH}\left(\mathrm{CH}_{2}\right)_{2} \mathrm{OH}, \mathrm{NH}_{(} \mathrm{CH}_{2}\right)_{2} \mathrm{CH}_{3}$

3. $\mathrm{X}=\mathrm{CH}\left(\mathrm{CH}_{3}\right) \mathrm{CH}_{2}, \mathrm{R}=\mathrm{OCH}_{3}, \mathrm{OCH}_{2} \mathrm{CH}_{3}$

Figure 5. Schematic Formulas of Cis-Diam(m)inebis(carboxylato)Dichloride Platinum (IV) and Cis-diam(m)inetetrakis(carboxylato) Platinum (IV) Complexes Investigated by Keppler's group.

a prodrug of cisplatinin in vivo [52] [53]. Satraplatin, as the first orally given Platinum (IV) complex, shows a comparable activity to cisplatin and carboplatin [10] [54]. In Phase I clinical trials, it was found to be lack of neurotoxicity and 
<smiles>ClP1(Cl)(Cl)NC2CCCCC2N1</smiles>

Tetraplatin

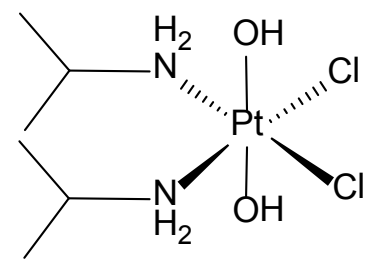

Iproplatin<smiles>NP(N)(O)(Cl)Cl</smiles>

Oxoplatin

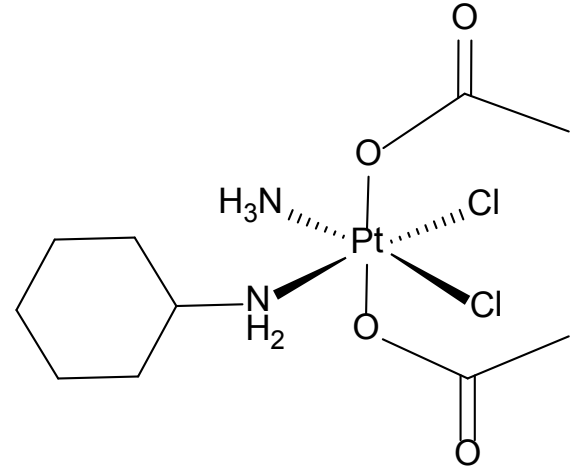

Satraplatin<smiles>CC(=O)O[P@@](N)(Cl)P(N)(Cl)(Cl)OC(C)=O</smiles>

LA-12

Figure 6. Chemical structures of the Platinum (IV) compounds that have entered in clinical trials or have been used clinically.

nephrotoxicity [55]. In 2003, satraplatin entered Phase III trials for the treatment of hormone refractory prostate cancer in a combination regimen with prednisone [44]. Although phase III clinical experiments of satraplatin in Europe and the US for ovarian, non-small-cell lung and small cell lung cancers had been completed, it was not approved by the FDA in clinical use for cancer treatment due to variability in drug uptake and poor therapeutic effect [56] [57]. Now clinical trials with satraplatin in a combination regime are ongoing. It was found the combination of satraplatin and fractionated radiotherapy is more effective against human lung cancer xenografts than either agent alone [58].

Another Pt (IV) complex, namely LA-12, demonstrated high cytotoxic effect in cisplatin-resistant cancer cell lines and no cross-resistance with cisplatin was seen [59]. In both murine ADJ/PC6 plasmacytoma and a human A2780 ovarian carcinoma tumor model, higher in vivo antitumor activity was observed compared to cisplatin and satraplatin [60]. Surprisingly, the acute toxicity of LA-12 in mice is relatively low and the effective dose is comparable to that of cisplatin and higher than that of satraplatin [60]. Currently, phase I clinical trials of LA-12 are in progress and some promising results have been shown [61].

Although all the examples discussed above are not approved by FDA, the stuies on them provide a basis for design and development of the new Platinum (IV). In addition to above Pt (IV)-prodrugs that entail chemical activation, photoactivatable Pt (IV) complexes also have attracted a great deal of attention in 
recent years.

\section{Photoactivatable Platinum (IV) Complexes}

The phototherapeutic method that has seen the greatest success in the treatment of cancer has been photodynamic therapy (PDT), which is based on the administration of a photosensitizer and subsequent activation using light at a wavelength where the compound absorbs. The photoactivatable prodrugs ideally should have good aqueous solubility, be activated by longer wavelength light for deeper penetration into the tissue, no dark toxicity, preferential accumulation in the cancer tissue, and finally a long enough half-life in the blood to reach the tumour cells in adequate concentrations [62] [63].

Recently, photoactivatable Pt (IV) complexes have been attached great importance with scientists. They are remarkably stable in the dark, even in the presence of cellular reducing agents such as glutathione, but readily undergo photoinduced ligand substitution and photoreduction reactions. Two classes of photoactivatable Pt (IV) complexes have been looked at thus far: diiodo-Pt (IV) and diazido-(IV) diammine complexes. The first generation of $\mathrm{Pt}$ (IV) photoactivatable anticancer drugs are diiodocomplexes (Figure 7), with the general formula of trans, cis- $\left[\mathrm{Pt}(\mathrm{X})_{2} \mathrm{I}_{2}(\mathrm{en})\right]$, where en $=$ ethylenediamine and $\mathrm{X}=\mathrm{Cl}^{-}$, $\mathrm{OH}^{-}$, acetate or methylsulfonate [64]. These diiodo-Pt (IV) complexes react to visible light by binding irreversibly to DNA. Furthermore, the photolysis products are cytotoxic to human cancer cells in vitro. Nevertheless, these complexes showed no significant difference between dark and light toxicity. It might be that these complexes are too reactive towards biological thiols, which rapidly reduced them to cytotoxic platinum (II) species, thus making them unsuitable as drugs [65] [66].

The second generation, diazido-Pt (IV) complexes (Figure 8), represented by cis, trans, cis- $\left[\mathrm{Pt}\left(\mathrm{N}_{3}\right)_{2}(\mathrm{OH})_{2}\left(\mathrm{NH}_{3}\right)_{2}\right]$ and cis, trans- $\left[\mathrm{Pt}(\mathrm{en})\left(\mathrm{N}_{3}\right)_{2}(\mathrm{OH})_{2}\right]$, are also photosensitive, binding irreversibly to DNA [65]. They are found to be stable to glutathione and thus show very low dark cytotoxicity, which is a desirable feature for photoactivatable drugs [67]. Interestingly, it was found that all the trans analog, trans, trans, trans, $-\left[\mathrm{Pt}\left(\mathrm{N}_{3}\right)_{2}(\mathrm{OH})_{2}\left(\mathrm{NH}_{3}\right)_{2}\right]$ is non-toxic to the cell in the dark, but as active as cisplatin in the light [68].

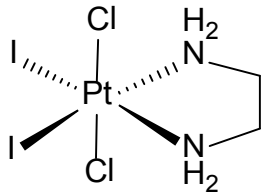

A

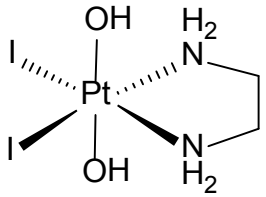

B

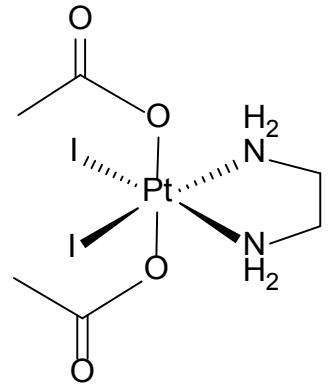

C

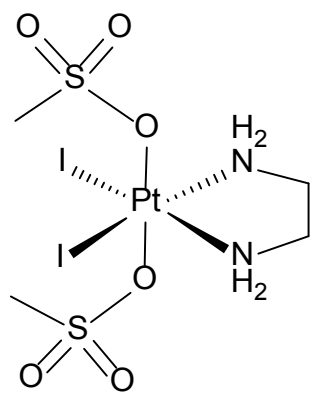

D

Figure 7. First Generation of diiodo photoactivatable Pt (IV) drugs. 
<smiles></smiles>

1<smiles></smiles>

2

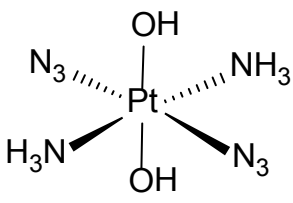

3

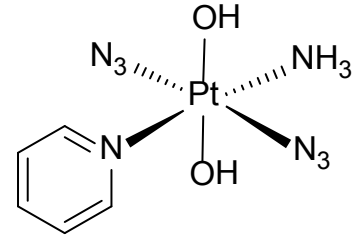

4

Figure 8. The second generation of Pt (IV)—diazido complexes.

Complex 4, which contains a pyridine instead of an ammine ligand, was significantly more potent than both above mentioned in vivo when irradiated with UV light [69]. And no cross-resistance was observed in cisplatin-resistant celllines [70]. Studies on the mechanism of action performed for the complexes by Berdnaski et al. [71] suggested that the mechanism of cytotoxicity in vitro is the same as that of cisplatin. These studies show that photoactivatable Platinum (IV) antitumor agents represent a promising area for new drug development.

\section{Conclusions}

Over the past decade, experimental and clinical studies on platinum-derived compounds have led to the development of potent anticancer drugs. During the process, Platinum (IV) complexes have attracted scientists' great attention and favor as it offers the opportunity to overcome some of the problems faced with cisplatin use. Platinum (IV) complexes provide several advantages over platinum (II) drugs, such as prolonged stability in the bloodstream, lower toxicity and efficacy in cisplatin-resistant tumor cell lines. Furthermore, Platinum (IV) complexes may be suitable for oral application.

The general structure formula of $\mathrm{Pt}(\mathrm{IV})$ complexesis cis, cis, trans-[Pt( $\left.\mathrm{Am})_{2} \mathrm{X}_{2} \mathrm{Y}_{2}\right]$. Wherein $\mathrm{X}$ is a leaving group and Am contains amino ligands, while $\mathrm{Y}$ is axial ligands. Modification of the leaving group(s) influences both biodistribution and the general toxicity. On the contrary, modification of the amine ligand(s) will influence the anticancer properties. The axial ligands can be changed to reduce the side effects, increase the activity of the complexes or confer additional cytotoxicity. The preparation of $\mathrm{Pt}$ (IV) complexes commences with constructing the corresponding Pt (II) complexes, which can be transformed into Pt (IV) complexes by ligand substitution or oxidation reaction with chlorines or hydrogen peroxide.

It is widely believed that reduction to platinum (II) by bio-reductants in body liquids, is essential for Platinum (IV) complexes to exert their anticancer activity. The platinum (II) species resulting from the reduction of the Pt (IV) complexes form adducts with DNA, causing conformational changes of DNA and destructing the biological function of DNA, thereby exerting anticancer activity. Choi et al. found that the complex with a bulkier and more electron withdrawing ligand showed a higher reduction rate and reduction potential. But there is no strong correlation between the anticancer activity and the reduction rate overall. Pt (IV) antitumor agents with higher lipophilicity would be more effective in 
cancer cells. However, an excessive increase in lipophilicity strongly decreases the water solubility and its hydrogen bonding ability, thus limiting bioavailability. Therefore, an oral candidate drug must be of an appropriate size, lipophilicity and hydrogen bonding characteristics to facilitate oral absorption.

Iproplatin, Ormaplatin (tetraplatin), oxoplatin, LA-12 and satraplatin have so far been in clinical trials or have been used clinically (oxoplatin). The first two have been abandoned. Iproplatin showed less cytotoxicity than cisplatin and tetraplatin was too toxic, whereas satraplatin is now being trialled for combination therapy. LA-12 is currently under phase I clinical trials.

In addition to the above-mentioned examples entailing chemical activation, photoactivable Pt (IV) complexes are also a class of promising candidates to avoid damage to healthy cells and the surrounding tissue. Recent studies show that the Pt (IV) diazido complexes with a trans geometry and aromatic amines show a remarkable set of desirable features such as stability in the dark, limiting dark toxicity, high aqueous solubility, high phototoxicity when irradiated with blue light and are promising candidates for use in cancer chemotherapy.

This mini-review on Pt (IV) complexes can help guide clinical development, provide a basis for progressing a new platinum compound, or lead to new classes of compounds.

\section{References}

[1] Jemal, A., Bray, F. and Ferlay, J. (2011) Global Cancer Statistics. CA: A Cancer Journal for Clinicians, 61, 69-90. https://doi.org/10.3322/caac.20107

[2] Harper, B.W., Krause-Heuer, A.M., Grant, M.P., Manohar, M., Garbutcheon-Singh, K.B. and Aldrich-Wright, J.R. (2010) Advances in Platinum Chemotherapeutics. Chemistry-A European Journal, 16, 7064-7077. https://doi.org/10.1002/chem.201000148

[3] Rosenberg, B., Camp, L.V. and Krigas, T. (1965) Inhibition of Cell Division in Escherichia coli by Electrolysis Products from a Platinum Electrode. Nature (London), 205, 698. https://doi.org/10.1038/205698a0

[4] Kelland, L. (2007) The Resurgence of Platinum-Based Cancer Chemotherapy. Nature Reviews Cancer, 7, 573-584. https://doi.org/10.1038/nrc2167

[5] Horwich, A., Shipley, J. and Huddart, R. (2006) Testicular Germ-Cell Cancer. Lancet, 367, 754-765. https://doi.org/10.1016/S0140-6736(06)68305-0

[6] Dahr, S., Kolishetti, N., Lippard, S.J. and Farokhzad, O.C. (2011) Targeted Delivery of a Cisplatin Prodrug for Safer and More Effective Prostate Cancer Therapy in Vivo. Proceedings of the National Academy of Sciences of the United States of America, 108, 1850-1855. https://doi.org/10.1073/pnas.1011379108

[7] Olszewski, U. and Hamilton, G. (2010) A Better Platinum-Based Anticancer Drug Yet to Come? Journal of Medicinal Chemistry, 10, 293-301.

[8] Shen, D.W., Pouliot, L.M., Hall, M.D. and Gottesman, M.M. (2012) Cisplatin Resistance: A Cellular Self-Defense Mechanism Resulting from Multiple Epigenetic and Genetic Changes. Pharmacological Reviews, 64, 706-721.

https://doi.org/10.1124/pr.111.005637

[9] Urien, S., Brain, E., Bugat, R., Pivot, X., Lochon, I., Van, M.L., Vauzelle, F. and Lokiec, F. (2005) Pharmacokinetics of Platinum after Oral or Intravenous Cisplatin: A 
Phase 1 Study in 32 Adult Patients. Cancer Chemotherapy and Pharmacology, 55 55-60. https://doi.org/10.1007/s00280-004-0852-8

[10] Johnstone, T.C., Suntharalingam, K. and Lippard, S.J. (2016) The Next Generation of Platinum Drugs: Targeted Pt(II) Agents, Nanoparticle Delivery, and Pt(IV) Prodrugs. Chemical Reviews, 116, 3436-3486. https://doi.org/10.1021/acs.chemrev.5b00597

[11] Hall, M.D., Mellor, H.R., Callaghan, R., et al. (2007) Basis for Design and Development of Platinum(IV) Anticancer Complexes. Journal of Medicinal Chemistry, 50, 3403-3411. https://doi.org/10.1021/jm070280u

[12] Giandomenico, C.M., Abrams, M.J., Murrer, B.A., Vollano, J.F., Rheinheimer, M.I., Wyer, S.B., Bossard, G.E., and Higgins, J.D. (1995) Carboxylation of Kinetically Inert Platinum(IV) Hydroxy Complexes. An Entr.acte.ee into Orally Active Platinum(IV) Antitumor Agents. Inorganic Chemistry, 34, 1015-1021.

https://doi.org/10.1021/ic00109a004

[13] Min, Y., Mao, C., Xu, D., Wang, J. and Liu, Y. (2010) Gold Nanorods for Platinum Based Prodrug Delivery. Chemical Communications, 46, 8424-8426. https://doi.org/10.1039/c0cc03108a

[14] Wong, E. and Giandornenico, C.M. (1999) Current Status of Platinum-Based Antitumor Drugs. Chemical Reviews, 99, 2451-2466. https://doi.org/10.1021/cr980420v

[15] Cohen, S.M. and Lippard, S.J. (2001) Cisplatin: From DNA Damage to Cancer Chemotherapy. Progress in Nucleic Acid Research and Molecular Biology, 67, 93-130.

[16] Siddik, Z.H. (2003) Cisplatin: Mode of Cytotoxic Action and Molecular Basis of Resistance. Oncogene, 22, 7265-7279. https://doi.org/10.1038/sj.onc.1206933

[17] Fuertes, M.A., Alonso, C. and Perez, J.M. (2003) Biochemical Modulation of Cisplatin Mechanisms of Action: Enhancement of Antitumor Activity and Circumvention of Drug Resistance. Chemical Reviews, 103, 645-662. https://doi.org/10.1021/cr020010d

[18] Braddock, P.D., Connors, T.A., Jones, M., Khokhar, A.R., Melzack, D.H. and Tobe, M.L. (1975) Structure and Activity Relationships of Platinum Complexes with Anti-Tumour Activity. Chemico-Biological Interactions, 11, 145-161.

[19] Prestayko, A.W., Bradner, W.T., Huftalen, J.B., Rose, W.C., Schurig, J.E., Cleare, M.J., Hydes, P.C. and Crooke, S.T. (1979) Antileukemia (L1210) Activity and Toxicity of cis-dichlorodiammineplatinum(II) Analogs. Cancer Treatment Reports, 63, 1503-1508.

[20] Turell, L., Radi, R. and Alvarez, B. (2013) The Thiol Pool in Human Plasma: The Central Contribution of Albumin to Redox Processes. Free Radical Biology and Medicine, 65, 244-253. https://doi.org/10.1016/j.freeradbiomed.2013.05.050

[21] Rieter, W.J., Pott, K.M., Taylor, K.M.L. and Lin, W. (2008) Nanoscale Coordination Polymers for Platinum-Based Anticancer Drug Delivery. Journal of the American Chemical Society, 130, 11584-11585. https://doi.org/10.1021/ja803383k

[22] Roat, R.M. and Reedijk, J. (1993) Reaction of mer-Trichloro (Diethylenetriamine)Platmum(IV) Chloride, $\left(\operatorname{mer}-\left[\mathrm{Pt}(\operatorname{dien}) \mathrm{Cl}_{3}\right] \mathrm{Cl}\right)$, with Purine Nucleosides and Nucleotides Results in Formation of Platinum(II) as Well as Platinum(IV) Complexes. Journal of Inorganic Biochemistry, 52, 263-274. https://doi.org/10.1016/0162-0134(93)80030-D

[23] Dhar, S.J., Daniel, W.L., Giljohann, D.A., Mirkin, C.A. and Lippard, S.J. (2009) Polyvalent Oligonucleotide Gold Nanoparticle Conjugates as Delivery Vehicles for 
Platinum(IV) Warheads. Journal of the American Chemical Society, 131, 14652-14653. https://doi.org/10.1021/ja9071282

[24] Vrana, O., Brabec, V. and Kleinwachter, V. (1986) Polarographic Studies on the Conformation of Some Platinum Complexes: Relations to Anti-Tumour Activity. Anti-Cancer Drug Design, 1, 95-109.

[25] Choi, S., Delaney, S., Orbai, L., Padgett, E.J. and Hakemian, A.S. (2001) A platinum(IV) Complex Oxidizes Guanine to 8-oxo-guanine in DNA and RNA. Inorganic Chemistry, 40, 5481-5482..

[26] Gibson, D. (2009) The Mechanism of Action of Platinum Anticancer Agents-What Do We Really Know about It? Dalton Transactions, No. 48, 10681-10689.

https://doi.org/10.1039/b918871c

[27] Hall, M.D. and Hambley, T.W. (2002) Platinum(IV) Antitumour Compounds: Their Bioinorganic Chemistry. Coordination Chemistry Reviews, 232, 49-67. https://doi.org/10.1016/S0010-8545(02)00026-7

[28] Hambley, T.W., Battle, A.R., Deacon, G.B., Lawrenz, E.T., Fallon, G.D., Gatehouse, B.M., Webster, L.K. and Rainone, S. (1999) Modifying the Properties of Platinum(IV) Complexes in Order to Increase Biological Effectiveness. Journal of Inorganic Biochemistry, 77, 3-12. https://doi.org/10.1016/S0162-0134(99)00133-6

[29] Galanski, M., Jakupec, M.A. and Keppler, B.K. (2005) Update of the Preclinical Situation of Anticancer Platinum Complexes: Novel Design Strategies and Innovative Analytical Approaches. Current Medicinal Chemistry, 12, 2075-2094. https://doi.org/10.2174/0929867054637626

[30] Hall, M.D., Amjadi, S., Zhang, M., Beale, P.J. and Hambley, T.W. (2004) The Mechanism of Action of Platinum(IV) Complexes in Ovarian Cancer Cell Lines. Journal of Inorganic Biochemistry, 98, 1614-1624. https://doi.org/10.1016/j.jinorgbio.2004.05.017

[31] Choi, S., Filotto, C., Bisanzo, M., Delaney, S., Lagasee, D., Whitworth, J.L., Jusko, A., Li, C.R., Wood, N.A., Willingham, J., Schwenker, A. and Spaulding, K. (1998) Reduction and Anticancer Activity of Platinum(IV) Complexes. Inorganic Chemistry, 37, 2500-2504. https://doi.org/10.1021/ic971047x

[32] Giandomenico, C.M., Abrams, M.J., Murrer, B.A., Vollano, J.F., Rheinheimer, M.I., Wyer, S.B., Bossard, G.E. and Higgins, J.D. (1995) Carboxylation of Kinetically Inert Platinum(IV) Hydroxy Complexes. An Entr.acte.ee into Orally Active Platinum(IV) Antitumor Agents. Inorganic Chemistry, 34, 1015-1021. https://doi.org/10.1021/ic00109a004

[33] Rodriguez-Nieto, S. and Zhivotovsky, B. (2006) Role of Alterations in the Apoptotic Machinery in Sensitivity of Cancer Cells to Treatment. Current Pharmaceutical Design, 12, 4411-4425. https://doi.org/10.2174/138161206779010495

[34] Kelland, L.R., Abel, G., McKeage, M.J., Jones, M., Goddard, P.M., Valenti, M., Murrer, B.A. and Harrap, K.R. (1993) Preclinical Antitumor Evaluation of Bis-Acetato-Ammine-Dichloro-Cyclohexylamine Platinum(IV): An Orally Active Platinum Drug. Cancer Research, 53, 2581-2586.

[35] Sharp, S.Y., Rogers, P.M. and Kelland, L.R. (1995) Transport of Cisplatin and Bis-Acetato-Ammine-Dichlorocyclohexylamine Platinum(IV) (JM216) in Human Ovarian Carcinoma Cell Lines: Identification of a Plasma Membrane Protein Associated with Cisplatin Resistance. Clinical Cancer Research, 1, 981-989.

[36] Zanellato, I., Bonarrigo, I., Colangelo, D., Gabano, E., Ravera, M., Alessio, M. and Osella, D. (2014) Biological Activity of a Series of Cisplatin-Based Aliphatic Bis(Carboxylato) Pt(IV) Prodrugs: How Long the Organic Chain Should Be? Jour- 
nal of Inorganic Biochemistry, 140, 219-227.

https://doi.org/10.1016/j.jinorgbio.2014.07.018

[37] Kostova, I. (2006) Platinum Complexes as Anticancer Agents. Recent Patents on Anti-Cancer Drug Discovery, 1, 1-22.

[38] Sebesta, F. and Burda, J.V. (2016) Reduction Process of Tetraplatin in the Presence of Deoxyguanosine Monophosphate (dGMP): A Computational DFT Study. Chemistry: A European Journal, 22, 1037-1047. https://doi.org/10.1002/chem.201503555

[39] Kipouros, I., Fica-Contreras, S.M., Bowe, G.J.K. and Choi, S. (2015) Oxidation of 5'-dGMP, 5'-dGDP, and 5'-dGTP by a Platinum(IV) Complex. Journal of Biological Inorganic Chemistry, 20, 1327-1341. https://doi.org/10.1007/s00775-015-1312-0

[40] Bednarski, P.J., Mackay, F.S. and Sadler, P.J. (2007) Photoactivatable Platinum Complexes. Anti-Cancer Agents in Medicinal Chemistry, 7, 75-93. https://doi.org/10.2174/187152007779314053

[41] Farrell, N.P. (2004) Preclinical Perspectives on the Use of Platinum Compounds in Cancer Chemotherapy. Seminars in Oncology, 31, 1-9. https://doi.org/10.1053/j.seminoncol.2004.11.004

[42] Dolman, R.C., Deacon, G.B. and Hambley, T.W. (2002) Studies of the Binding of a Series of Platinum(IV) Complexes to Plasma Proteins. Journal of Inorganic Biochemistry, 88, 260-267. https://doi.org/10.1016/S0162-0134(01)00360-9

[43] Hall, M.D., Alderden, R.A., Zhang, M., et al. (2006) The Fate of Platinum(II) and Platinum(IV) Anti-Cancer Agents in Cancer Cells and Tumours. Journal of Structural Biology, 155, 38-44. https://doi.org/10.1016/j.jsb.2006.01.011

[44] Choy, H., Park, C. and Yao, M. (2008) Current Status and Future Prospects for Satraplatin, an Oral Platinum Analogue. Clinical Cancer Research, 14, 1633-1638. https://doi.org/10.1158/1078-0432.CCR-07-2176

[45] Moghaddas, S., Majmudar, P., Marin, R., Dezvareh, H., Qi, C., Soans, E. and Bose, R.N. (2012) Phosphaplatins, Next Generation Platinum Antitumor Agents: A Paradigm Shift in Designing and Defining Molecular Targets. Inorganica Chimica Acta, 393, 173-181. https://doi.org/10.1016/j.ica.2012.05.040

[46] Varbanov, H., Valiahdi, S.M., Jakupec, M.A., Galanski, M. and Keppler, B.K. (2012) Novel Tetracarboxylatoplatinum(IV) Complexes as Carboplatin Prodrugs. Dalton Transactions, 41, 14404-14415. https://doi.org/10.1039/c2dt31366a

[47] Reithofer, M., Galanski, M., Roller, A. and Keppler, B.K. (2006) An Entry to Novel Platinum Complexes: Carboxylation of Dihydroxoplatinum(IV) Complexes with Succinic Anhydride and Subsequent Derivatization. European Journal of Inorganic Chemistry, No. 13, 2612-2617. https://doi.org/10.1002/ejic.200600108

[48] Reithofer, M.R., Valiahdi, S.M., Jakupec, M.A., Arion, V.B., Egger, A., Galanski, M. and Keppler, B.K. (2007) Novel Di- and Tetracarboxylatoplatinum(IV) Complexes. Synthesis, Characterization, Cytotoxic Activity, and DNA Platination. Journal of Medicinal Chemistry, 50, 6692-6699. https://doi.org/10.1021/jm070897b

[49] Reithofer, M.R., Schwarzinger, A., Valiahdi, S.M., Galanski, M., Jakupec, M.A. and Keppler, B.K. (2008) Novel Bis(carboxylato)dichlorido(ethane-1,2-diamine)platinum(IV) Complexes with Exceptionally High Cytotoxicity. Journal of Inorganic Biochemistry, 102, 2072-2077. https://doi.org/10.1016/j.jinorgbio.2008.07.006

[50] Varbanov, H., Valiahdi, S.M., Legin, A.A., Jakupec, M.A., Roller, A., Galanski, M. and Keppler, B.K. (2011) Synthesis and Characterization of Novel Bis(carboxylato)dichloridobis(ethylamine)platinum(IV) Complexes with Higher Cytotoxicity than Cisplatin. European Journal of Medicinal Chemistry, 46, 5456-5464. https://doi.org/10.1016/j.ejmech.2011.09.006 
[51] Braddock, P.D., Connors, T.A., Jones, M., Khokhar, A.R., Melzack, D.H. and Tobe, M.L. (1975) Structure and Activity Relationships of Platinum Complexes with Anti-Tumour Activity. Chemico-Biological Interactions, 11, 145-161. https://doi.org/10.1016/0009-2797(75)90095-2

[52] Hamberger, J., Liebeke, M., Kaiser, M., Bracht, K., Olszewski, U., Zeillinger, R., et al. (2009) Characterization of Chemosensitivity and Resistance of Human Cancer Cell Lines to Platinum(II) versus Platinum(IV) Anticancer Agents. Anti-Cancer Drugs, 20, 559-572. https://doi.org/10.1097/CAD.0b013e32832d513b

[53] Hamilton, G. (2014) Comparison of Intracellular Stress Response of NCI-H526 Small Cell Lung Cancer (SCLC) Cells to Platinum(II) Cisplatin and Platinum(IV) Oxoplatin. Cancers, 6, 1487-1499. https://doi.org/10.3390/cancers6031487

[54] Rose, W.C., Crosswell, A.R., Schruig, J.E. and Casazza, A.M. (1993) Preclinical Antitumor Activity of Orally Administered Platinum (IV) Complexes. Cancer Chemotherapy and Pharmacology, 32, 197-203. https://doi.org/10.1007/BF00685835

[55] McKeage, M.J., Raynaud, F.,Ward, J., Berry, C., O’Dell, D., Kelland, L.R., Murrer, B., Santabarabara, P., Harrap, K.R. and Judson, I.R. (1997) Phase I and Pharmacokinetic Study of an Oral Platinum Complex Given Daily for 5 Days in Patients with Cancer. Journal of Clinical Oncology, 15, 2691-2700. https://doi.org/10.1200/JCO.1997.15.7.2691

[56] Doshi, G., Sonpavde, G. and Sternberg, C.N. (2012) Clinical and Pharmacokinetic Evaluation of Satraplatin. Expert Opinion on Drug Metabolism \& Toxicology, 8, 103-111. https://doi.org/10.1517/17425255.2012.636352

[57] Hamilton, G. and Olszewski, U. (2013) Picoplatin Pharmacokinetics and Chemotherapy of Non-Small Cell Lung Cancer. Expert Opinion on Drug Metabolism \& Toxicology, 9, 1381-1390. https://doi.org/10.1517/17425255.2013.815724

[58] Figg, W.D., Chau, C.H., Madan, R.A., Gulley, J.L., Gao, R., Sissung, T.M., Spencer, S., Beatson, M., Aragon-Ching, J., Steinberg, S.M. and Dahut, W.L. (2013) Phase II Study of Satraplatin and Prednisone in Patients with Metastatic Castration-Resistant Prostate Cancer: A Pharmacogenetic Assessment of Outcome and Toxicity. Clinical Genitourinary Cancer, 11, 229-237.

[59] Žák, F., Turánek, J., Kroutil, A., et al. (2004) Platinum(IV) Complex with Adamantylamine as Nonleaving Amine Group: Synthesis, Characterization, and in Vitro Antitumor Activity against a Panel of Cisplatin-Resistant Cancer Cell Lines. Journal of Medicinal Chemistry, 47, 761-763. https://doi.org/10.1021/jm030858+

[60] Sova, P., Mistr, A., Kroutil, A., Zak, F., Pouckova, P. and Zadinova, M. (2005) Preclinical Anti-Tumor Activity of a New Oral Platinum(IV) Drug LA-12. Anti-Cancer Drugs, 16, 653-657. https://doi.org/10.1097/00001813-200507000-00010

[61] Shaili, E. (2014) Platinum Anticancer Drugs and Photochemotherapeutic Agents: Recent Advances and Future Developments. Science Progress, 97, 20-40. https://doi.org/10.3184/003685014X13904811808460

[62] Bown, S.G. (2013) Photodynamic Therapy for Photochemists. Philosophical Transactions of the Royal Society A, 371, 371.

[63] Farrer, N.J., Salassa, L. and Sadler, P.J. (2009) Photoactivated Chemotherapy (PACT): The Potential of Excited-State d-Block Metals in Medicine. Dalton Transactions, No. 48, 10690-10701. https://doi.org/10.1039/b917753a

[64] Kratochwil, N.A. and Bednarski, P.J. (1999) Relationships between Reduction Properties and Cancer Cell Growth Inhibitory Activities of cis-Dichloro- and cis-Diiodo-Pt(IV)-ethylenediamines. Archiv der Pharmazie, 332, 279-285. https://doi.org/10.1002/(SICI)1521-4184(19998)332:8<279::AID-ARDP279>3.0.CO; $\underline{2-1}$ 
[65] Kratochwil, N.A., Zabel, M. and Bednarski, P.J. (1996) Synthesis and X-Ray Crystal Structure of trans,cis-[Pt(OAc) $\left.{ }_{2} \mathrm{I}_{2}(\mathrm{en})\right]$ : A Novel Type of Cisplatin Analog That Can Be Photolyzed by Visible Light to DNA-Binding and Cytotoxic Species in Vitro. Journal of Medicinal Chemistry, 39, 2499-2507. https://doi.org/10.1021/jm9509105

[66] Kratochwil, N.A., Guo, Z., del Socorro Murdoch, P., Parkinson, J.A., Bednarski, P.J. and Sadler, P.J. (1998) Electron-Transfer-Driven Trans-Ligand Labilization: A Novel Activation Mechanism for Pt(IV) Anticancer Complexes. Journal of the American Chemical Society, 120, 8253-8254. https://doi.org/10.1021/ja980393q

[67] Westendorf, A.F., Bodtke, A. and Bednarski, P.J. (2011) Studies on the Photoactivation of Two Cytotoxic trans,trans,trans-Diazidodiaminodihydroxo-Pt(IV) Complexes. Dalton Transactions, 40, 5342-5451. https://doi.org/10.1039/c0dt01485k

[68] Mackay, F.S., Woods, J.A., Moseley, H., Ferguson, J., Dawson, A., Parsons, S. and Sadler, P.J. (2006) A Photoactivated trans-Diammine Platinum Complex as Cytotoxic as Cisplatin. Chemistry. A European Journal, 12, 3155-3161.

https://doi.org/10.1002/chem.200501601

[69] Mackay, F.S., Woods, J.A., Heringová, P., Kaspárková, J., Pizarro, A.M., Moggach, S.A., et al. (2007) A Potent Cytotoxic Photoactivated Platinum Complex. Proceedings of the National Academy of Sciences of the United States of America, 104, 20743-20748. https://doi.org/10.1073/pnas.0707742105

[70] Westendorf, A.F., Woods, J.A., Korpis, K., Farrer, N.J., Salassa, L., Robinson, K., et al. (2012) Trans, trans, trans-[PtIV(N3) $\left.(\mathrm{OH})_{2}(\mathrm{py})\left(\mathrm{NH}_{3}\right)\right]$ : A Light-Activated Antitumor Platinum Complex That Kills Human Cancer Cells by an Apoptosis-Independent Mechanism. Molecular Cancer Therapeutics, 11, 1894-1904. https://doi.org/10.1158/1535-7163.MCT-11-0959

[71] Bednarski, P.J., Korpis, K., Westendorf, A.F., Perfahl, S. and Grünert, R. (2013) Effects of Light-Activated Diazido- $\mathrm{Pt}^{\mathrm{IV}}$ Complexes on Cancer Cells in Vitro. Philosophical Transactions of the Royal Society A, 371, Article ID: 20120118. https://doi.org/10.1098/rsta.2012.0118 